\title{
The application of APEX images in the assessment of the state of non-forest vegetation in the Karkonosze Mountains
}

\section{Abstract}

Information about vegetation condition is needed for the effective management of natural resources and the estimation of the effectiveness of nature conservation. The aim of the study was to analyse the condition of non-forest mountain communities: synanthropic communities and natural grasslands. UNESCO's M\&B Karkonosze Transboundary Biosphere Reserve was selected as the research area. The analysis was based on 40 field test polygons and APEX hyperspectral images. The field measurements allowed the collection of biophysical parameters - Leaf Area Index (LAI), fraction of Absorbed Photosynthetically Active Radiation (fAPAR) and chlorophyll content - which were correlated with vegetation indices calculated using the APEX images. Correlations were observed between the vegetation indices (general condition, plant structure) and total area of leaves (LAI), as well as fraction of Absorbed Photosynthetically Active Radiation (fAPAR). The outcomes show that the non-forest communities in the Karkonosze are in good condition, with the synanthropic communities characterised by better condition compared to the natural communities.

Keywords

Mountain meadows $\cdot$ vegetation condition $\cdot$ APEX $\cdot$ hyperspectal remote sensing $\bullet$ vegetation indices $\bullet$ biophysical parameters

(C) University of Warsaw - Faculty of Geography and Regional Studies
Anna M. Jarocińska ${ }^{1}$, Monika Kacprzyk ${ }^{1}$ Adriana Marcinkowska-Ochtyra', Adrian Ochtyra ${ }^{1,2}$, Bogdan Zagajewski ${ }^{1}$, Koen Meuleman ${ }^{3}$

'Department of Geoinformatics, Cartography and Remote Sensing, Faculty of Geography and Regional Studies, University of Warsaw, Poland e-mail: ajarocinska@uw.edu.pl e-mail: monika.kacprzyk@student.uw.edu.pl e-mail: adriana.marcinkowska@uw.edu.pl e-mail: adrian.ochtyra@uw.edu.pl e-mail: bogdan@uw.edu.pl

2University of Warsaw, College of Inter-Faculty Individual Studies in Mathematics and Natural Sciences, Poland e-mail: adrian.ochtyra@uw.edu.pl

${ }^{3}$ VITO - Centre for Remote Sensing and Earth

Observation Processes, Belgium

e-mail: koen.meuleman@vito.be

Received: 20 July 2015

Accepted: 10 February 2016
Introduction and motivations

Due to the low accessibility of mountain ecosystems, unstable weather conditions and the short vegetative season, remote sensing is a suitable tool for monitoring vegetation. Hyperspectral remote sensing, which is based on hundreds of very narrow spectral bands, offers a significant set of tools for monitoring vegetation data. It provides uniform treatment of the entire study area, is repeatable and can be used for large areas.

Hyperspectral techniques with a high spatial, spectral and radiometric resolution are very useful to vegetation mapping and condition analyses. The spectral characteristics of vegetation species or communities allow the assessment, for example, of chlorophyll, water content and internal leaf structure (Jensen 1983). Based on spectral bands it is possible to calculate vegetation indices in a non-destructive way (Ustin et al. 2004). Using vegetation indices and statistical methods, different biophysical parameters have been estimated - for example, LAI has been based on its relationship to vegetation indices (the highest $R^{2}$ value was 0.55 , He et al. 2006). In other analyses, LAI has been estimated using five vegetation indices, where the determination coefficient was $>0.68$ : for the Ratio Vegetation Index -0.749 , for the Normalized Difference Vegetation Index -0.748 , for the Perpendicular Vegetation Index -0.741 , for the Transformed Soil Adjusted Vegetation Index -0.681 , and for the Soil Adjusted Vegetation Index 2 - 0.786 (Darvishzadeh et al. 2006). HyMap images have also been used in monitoring biomass content in the Majella National Park in Italy (Cho \& Skidmore 2009). The authors correlated different vegetation indices with biomass, and a high correlation was observed $\left(R^{2} \geq 0.5\right)$. The fraction of
APAR has been estimated using the vegetation index NDVI (di Bella et al. 2004). A high correlation was noted between fAPAR for green leaves and NDVI $\left(R^{2}=0.78, n=16, \rho<0.001\right)$. A relationship between fAPAR and the NDVI at the top of the canopy was also noticed $\left(R^{2}=0.919\right)$ (Myneni \& Williams 1994). Field hyperspectral data have also been successfully used in Poland to estimate the biophysical properties of grasslands (Jarocińska 2014, Kycko et al. 2014).

The aim of the study is the application of airborne levelacquired hyperspectral APEX data to analyse the condition of non-forest mountain communities in the Karkonosze. In this study two types of non-forest communities are analysed: natural grassland and the synanthropic patterns of invasive species. Grasslands include alpine swards, meadows and dwarf shrubs.

\section{Research area}

The research area is the Karkonosze (Giant) Mountains located on the border between Poland and the Czech Republic (Figure 1). Detailed analyses are performed on two areas: (1) around Mala Úpa on the Czech and Polish side, (2) Velká Úpa and Pec pod Sněžkou on the Czech side. The first area is located at an altitude of around $1000 \mathrm{~m}$ a.s.l., the second area in the valleys at $725-800 \mathrm{~m}$ a.s.l.

The grasslands of the analysed areas consist of Poa pratensis L., Nardus Stricta, Trifolium L. and dwarf shrubs (Vaccinium myrtillus). The most common synanthropic plants are Lupinus polyphyllus L., Urtica dioica $L$. and Rumex alpinus $L$. The length of the growing season in the Karkonosze is quite short and depends 


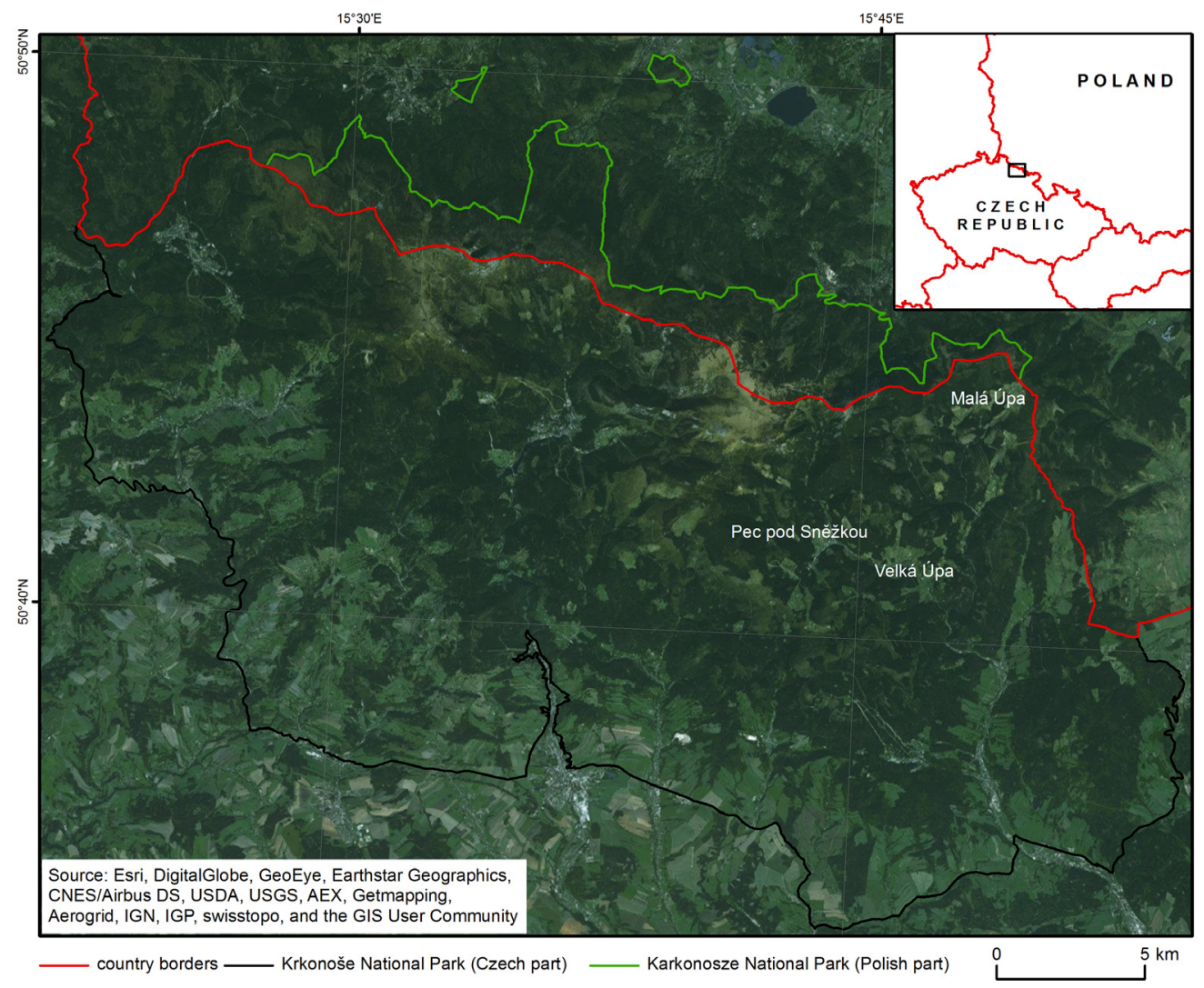

Figure 1. Location of the study area - Karkonosze National Park in Poland and Krkonoše National Park in the Czech Republic

on altitude (Żołnierz et al. 2012). In the upper regions of the hills, higher precipitation, fog, strong winds and intense solar radiation can be observed. During the winter, areas exposed to the wind and not covered with snow can suffer from physiological drought. As a result, plants have acquired a number of adaptations in terms of their structure, morphology and physiological processes in order to survive these conditions (Żołnierz \& Wojtuń 2013). The plants get smaller with increasing altitude and also have a different morphological structure (e.g. waxes, small leaves).

This area has been analysed using APEX images to classify the different vegetation communities in the Karkonosze Mountains (Marcinkowska et al. 2014), as well as in vegetation modelling (Jarocińska et al. 2014a) and plant condition analysis (Jelének et al. 2014).

\section{Methods and materials}

Field work

Field measurements were carried out on $28^{\text {th }}-30^{\text {th }}$ August 2013 on 37 research polygons: 30 polygons of grassland and 7 synanthropic communities (this number was much smaller, because synanthropic communities cover smaller patches). Biophysical parameters were acquired from areas of at least $3 \times 3$ APEX pixels $(9 \times 9 \mathrm{~m})$. The Leaf Area Index (LAI) was measured using the LAl-2000 Plant Canopy Analyzer. Each polygon was characterised by 2 independent sets of measurements. Each set consists of 3 measurements above canopy level and 15 measurements below canopy.

The AccuPAR Ceptometer model PAR 80 was used to measure Photosynthetically Active Radiation (PAR). Each polygon was characterised by 5 independent sets of measurements. Based on the PAR measurements 2 indices were calculated:
(1) Absorbed Photosynthetically Active Radiation (APAR) and (2) fraction of APAR (fAPAR), using the following equations:

$$
A P A R=\left(P A R_{0}+P A R_{S}\right)-\left(P A R_{C}+P A R_{T}\right)
$$

$\mathrm{PAR}_{0}$ - value of radiation incoming to the canopy

$\mathrm{PAR}_{\mathrm{S}}$ - value of radiation reflected from the soil

$P A R_{C}$ - value of radiation reflected from the canopy

$\mathrm{PAR}_{\mathrm{T}}$ - value of radiation transmitted through the canopy

$$
f A P A R=\frac{A P A R}{P A R_{0}}
$$

The Chlorophyll Content Index (CCl) was collected using the Chlorophyll Content Meter CCM-200 (10 samples for each polygon).

The values of chlorophyll content $(\mathrm{CCl})$, fraction of APAR (fAPAR) and Leaf Area Index (LAI) for each polygon were gathered in a database.

\section{Remote Sensing processing}

The APEX (Airborne Prism EXperiment) images were acquired on $10^{\text {th }}$ September 2012 by DLR (German Aerospace Center, DLR Braunschweig) and VITO (Centre for Remote Sensing and Earth Observation Processes, Mol, Belgium). The APEX scanner offers 288 spectral bands $(380-2500 \mathrm{~nm}$ ) and spatial resolution from 1.75 to 3.5 meters depending on the altitude of the aircraft. The images were radiometrically calibrated and corrected geometrically and atmospherically at the VITO office.

The first step of the analysis was focused on land cover classification: grasslands, synanthropic communities and the background (forests, anthropogenic area and others), which was masked. Training and verification polygons were drawn on the 
Table 1. Formulas of calculated vegetation indices

\begin{tabular}{|c|c|c|c|}
\hline Vegetation index & Name & Formula & Reference \\
\hline $\mathrm{mNDVI}_{705}$ & $\begin{array}{l}\text { modified Normalized Difference } \\
\text { Vegetation Index } 705\end{array}$ & $m N D V I_{705}=\frac{R_{750}-R_{705}}{R_{750}+R_{705}-2 R_{445}}$ & Sims \& Gamon 2002 \\
\hline PRI & Photochemical Reflectance Index & $P R I=\frac{R_{531}-R_{570}}{R_{531}+R_{570}}$ & Gamon et al. 1992 \\
\hline NDNI & $\begin{array}{l}\text { Normalized Difference Nitrogen } \\
\text { Index }\end{array}$ & $N D N I=\frac{\log \left(1 / R_{1510}\right)-\log \left(1 / R_{1680}\right)}{\log \left(1 / R_{1510}\right)+\log \left(1 / R_{1680}\right)}$ & Fourty et al. 1996 \\
\hline MSI & Moisture Stress Index & $M S I=\frac{R_{1599}}{R_{819}}$ & Hunt \& Rock 1989 \\
\hline WBI & Water Band Index & $W B I=\frac{R_{900}}{R_{970}}$ & Peñuelas et al. 1995 \\
\hline
\end{tabular}

images based on field measurements and photointerpretation. For three images, training (15637, 14738 and 13210 pixels) and verification patterns (29449, 22233 and 21637 pixels, respectively) were selected. Next, a Support Vector Machines ${ }^{1}$ classification with linear kernel was performed and the accuracy of the classification was checked using a confusion matrix. The results of the classification were used to mask the background.

Based on the APEX images, values were calculated for the vegetation indices (Table 1 ):

- $\quad$ modified Normalized Difference Vegetation Indices 705;

- Photochemical Reflectance Index;

- Normalized Difference Nitrogen Index;

- Water Band Index;

- Moisture Stress Index.

These indices were chosen to analyse the overall vegetation condition, chlorophyll content, vegetation productivity and water content. The values can be influenced by the plant structure, so they may be different for grasslands and synanthropic communities.

The polygons of the field-measured reference data were located on the images of vegetation indices. Each polygon represented an average value of 9 pixels. The values of indices were correlated with the field-acquired values of biophysical parameters (LAI, fAPAR and $\mathrm{CCl}$ ) to calculate the relationship between them (regression equations and coefficient of determination). This step was taken for grasslands only, because there were too few polygons for the synanthropic communities.

For each biophysical parameter the index with the best correlation (the highest value of coefficient of determination) was chosen. The regression equations for these indices were used to calculate the biophysical parameter using the APEX images (Table 2).

The results provided information about the vegetation condition - maps of the distribution of the vegetation indices for grasslands and synanthropic communities, and biophysical parameters LAI and fAPAR for grasslands.

\section{Results and Conclusions}

Based on the APEX data it was possible to classify the grassland and synanthropic community with an overall accuracy for the three images of $88.6 \%, 93 \%$ and $94.3 \%$ and with kappa coefficient $0.85,0.89$ and 0.86 , respectively. The vegetation communities were identified correctly.

${ }^{1}$ A supervised method of classification, based on patterns of learning and using the hyperplane with margins and support vectors to distinguish between classes (Hsu et al. 2010).
Table 2. Regression equations for biophysical parameters for grasslands

\begin{tabular}{|c|c|}
\hline Parameter & Grassland communities \\
\hline $\mathrm{N}$ & 30 \\
\hline LAl & $\mathrm{y}=-41.562 \times x+2.6944$ \\
$\mathrm{x}-\mathrm{PRI} ; \mathrm{R}^{2}=0.37$ \\
\hline fAPAR & $y=-3.9974 \times x+4.7248$ \\
& $x-\mathrm{WBI} ; \mathrm{R}^{2}=0.37$ \\
\hline
\end{tabular}

The correlations between the biophysical parameters and vegetation indices were not very precise, but it was possible to calculate maps of parameters for grasslands. The highest determination coefficient was 0.37 for LAl using the Photochemical Reflectance Index and also 0.37 for fAPAR using the Water Band Index. The best correlation between the Chlorophyll Content Index and vegetation indices was found for the Normalized Difference Nitrogen Index (with a determination coefficient of 0.31 ), but the values of $\mathrm{CCl}$ calculated based on this index were out of range compared to the values recorded during field measurements. This is most likely a result of the heterogeneity of the community. The analysed plants, such as Lupinus polyphyllus $L$. and Rumex alpinus $L$., are diverse and have different chlorophyll content. This may also be related to errors in the CCM-200 measurements. No values were obtained for synanthropic vegetation. The number of research polygons for synanthropic communities was too small, so the results were not reliable.

The results of correlation were worse compared to lowland areas (Jarocińska \& Zagajewski 2008). A better relationship $\left(R^{2}=0.77\right)$ has also been observed between the Simple Ratio index and biomass content in the alpine grasslands in south-eastern Switzerland (Rapp et al. 2013). To obtain better results, more field measurements should be collected representing different vegetation types (especially for synanthropic communities), and they should be collected at the same time as the flight campaign. Furthermore, the relationship between biophysical parameters and vegetation indices could be influenced by the amount of senescent leaves (di Bella et al. 2004).

The state of the canopy was analysed based on the values of the vegetation indices and biophysical parameters (Table 3). The average values of mNDVI 705 were around 0.5 , so the condition of the non-forest communities is quite good (Fig. 2). The differences between the vegetation indices for grasslands and synanthropic communities were not high, but noticeable. For the synanthropic 


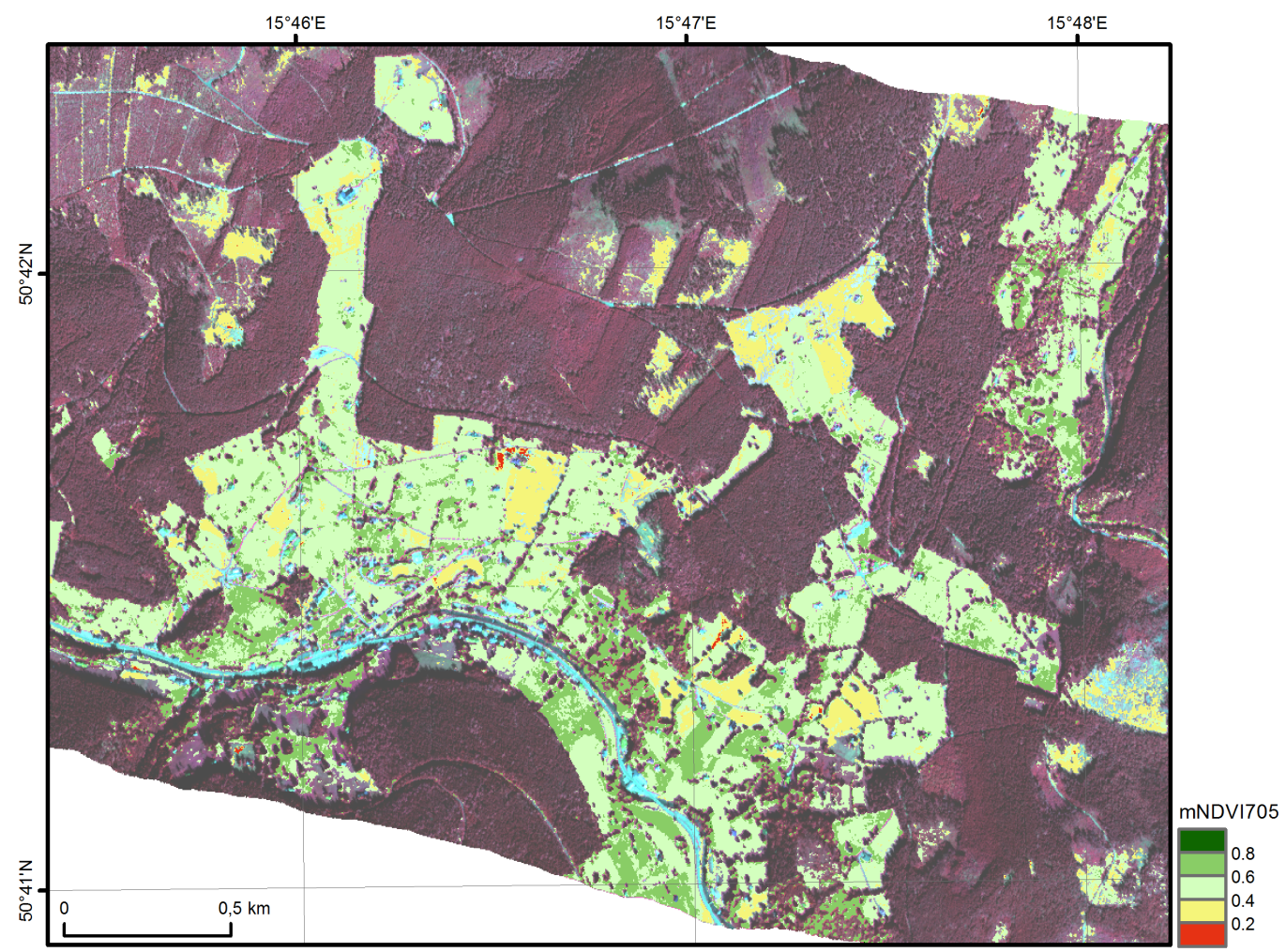

Figure 2. Distribution of the mNDVI vegetation index near Velká Úpa for non-forest communities. On a background APEX image with $R G B(\rho 862, \rho 649, \rho 547 \mathrm{~nm})$ composition with $30 \%$ transparency

Table 3. The average value and standard deviation of calculated vegetation indices and biophysical variables for different study areas

\begin{tabular}{|c|c|c|c|c|c|c|c|c|}
\hline \multirow{2}{*}{ Index } & \multicolumn{4}{|c|}{ Grassland communities } & \multicolumn{4}{c|}{ Synanthropic communities } \\
\cline { 2 - 10 } & $\begin{array}{c}\text { around Velká Úpa and } \\
\text { Pec pod Sněžkou }\end{array}$ & \multicolumn{2}{|c|}{ around Mala Úpa } & \multicolumn{2}{c|}{$\begin{array}{c}\text { around Velká Úpa and } \\
\text { Pec pod Sněžkou }\end{array}$} & \multicolumn{2}{c|}{ around Mala Úpa } \\
\cline { 2 - 9 } & Average & St. Dev. & Average & St. Dev. & Average & St. Dev. & Average & St. Dev. \\
\hline mNDVI705 & 0.52 & 0.171 & 0.44 & 0.132 & 0.51 & 0.235 & 0.52 & 0.268 \\
\hline PRI & -0.02 & 0.022 & -0.02 & 0.029 & -0.03 & 0.023 & 0.01 & 0.089 \\
\hline NDNI & 0.17 & 0.033 & 0.14 & 0.033 & 0.13 & 0.038 & 0.13 & 0.028 \\
\hline WBI & 1.00 & 0.069 & 0.98 & 0.067 & 1.02 & 0.093 & 1.01 & 0.135 \\
\hline MSI & 1.04 & 0.138 & 1.13 & 0.166 & 1.07 & 0.203 & 1.08 & 0.267 \\
\hline \multicolumn{2}{|c|}{ Biophysical variable } & & & & & & \\
\hline fAPA & 3.56 & 0.90 & 3.60 & 1.15 & & & & \\
\hline
\end{tabular}

communities, the values of mNDVI705 and PRI were higher and more diverse. The lower grassland values may be the result of different structure and chlorophyll content. Grasslands are also more homogeneous than synanthropic communities. The values of NDNI were higher for grasslands. Values for MSI and WBI showed that the plants were not under water stress, but the synanthropic communities had higher water content.

Two different areas were compared in the analysis: (1) around Velká Úpa and Pec pod Sněžkou and (2) around Mala Úpa. For the synanthropic communities the values of vegetation indices were similar in both areas, but around Mala Úpa the values of most indices (apart from NDNI) are more diverse. For the grasslands the differences were greater - the vegetation condition was better in the areas around Velká Úpa and Pec pod Sněžkou, i.e. at a lower altitude. This may be a result of the differences in altitude, climate and plant species.

Based on the vegetation indices, maps of the Leaf Area Index (Fig. 3) and the fraction of Absorbed Photosynthetically Active Radiation (Fig. 4) were calculated for the grasslands. The average value of LAI was around 3.56 in Velká Úpa and Pec pod 


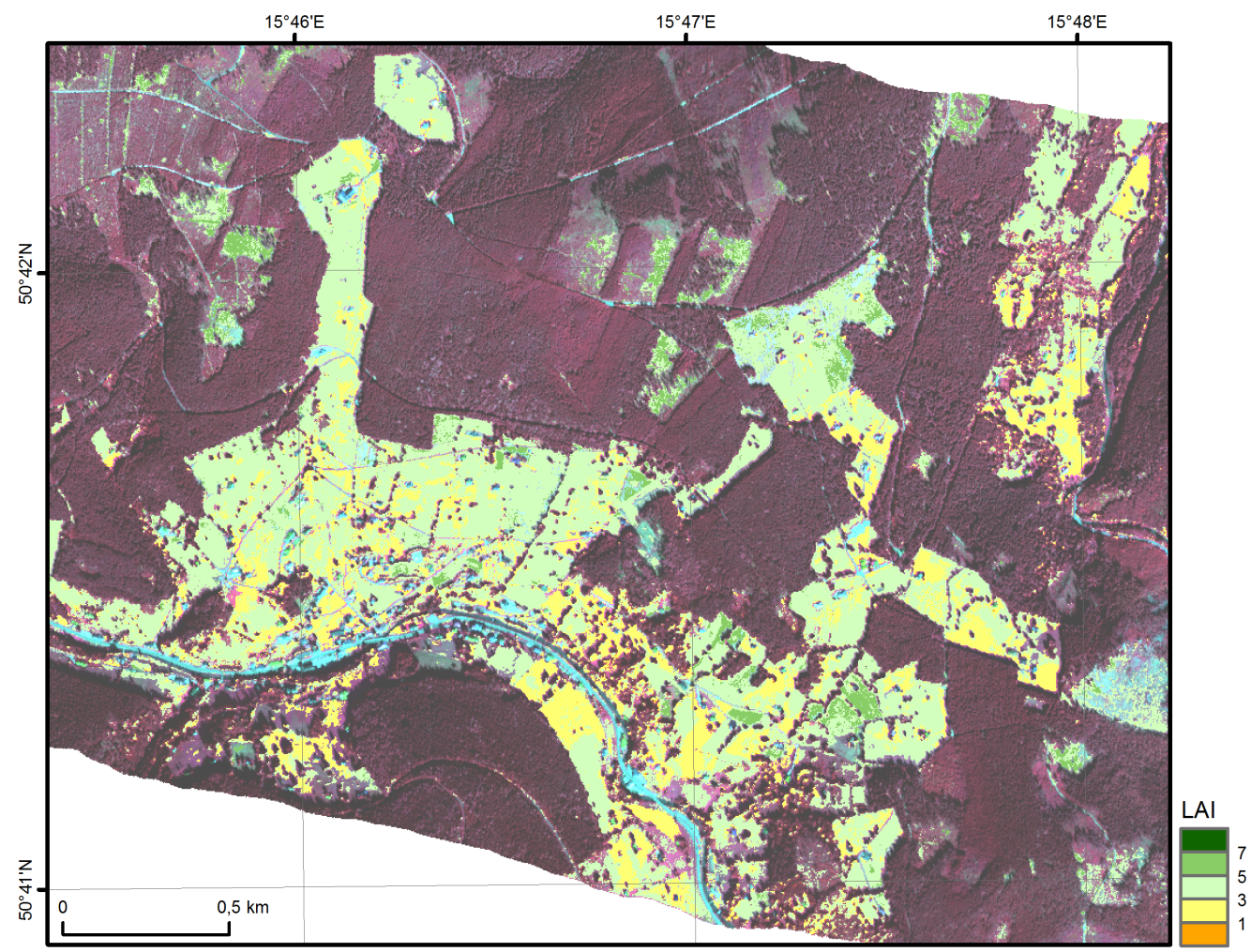

Figure 3. Distribution of the Leaf Area Index near Velká Úpa for grasslands. On a background APEX image with RGB ( $\rho 862, \rho 649$, $\rho 547 \mathrm{~nm}$ ) composition with $30 \%$ transparency

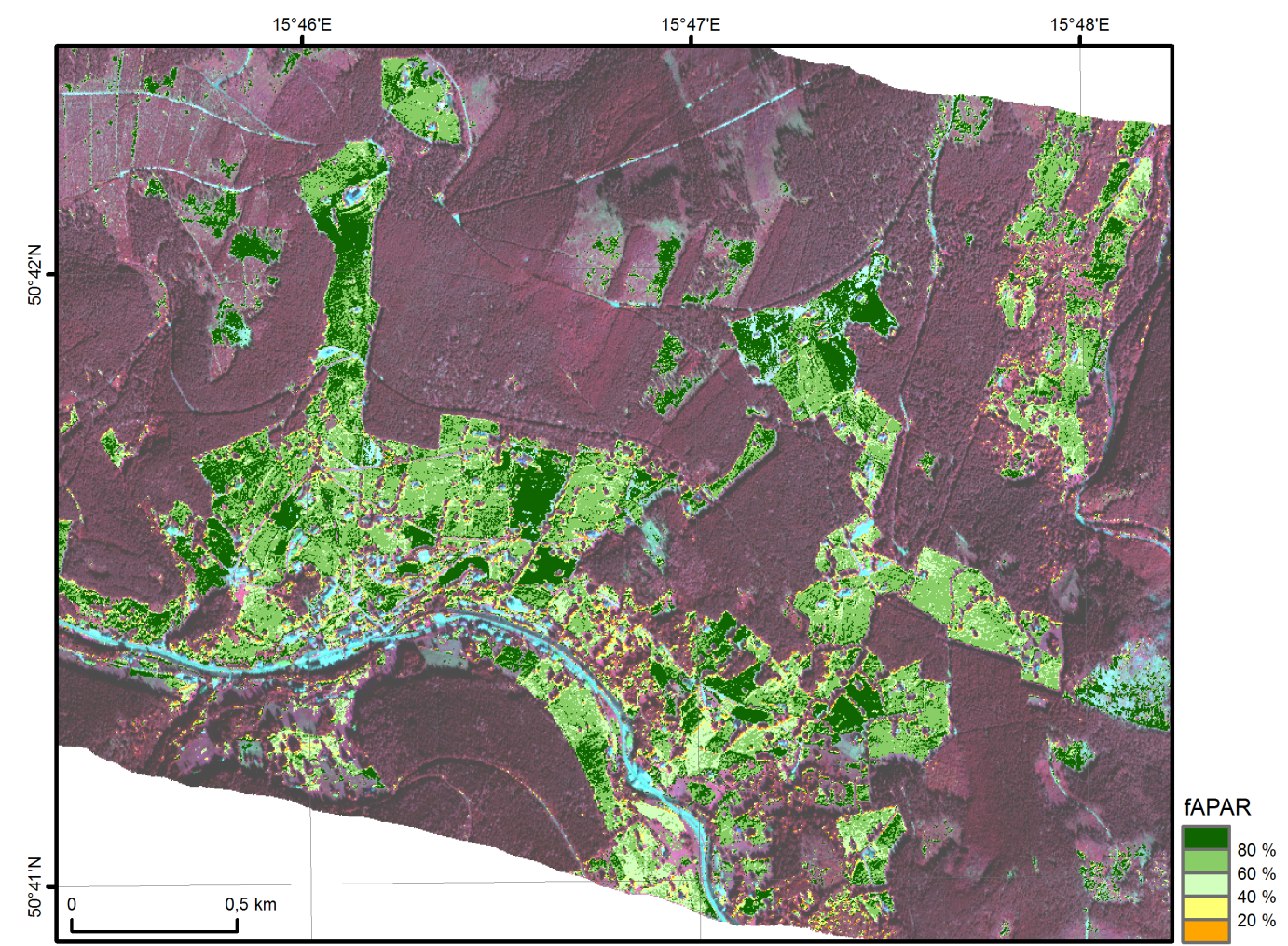

Figure 4. Distribution of the fAPAR vegetation index near Velká Úpa for grasslands. On a background APEX image with RGB ( $\rho 862$, $\rho 649, \rho 547 \mathrm{~nm}$ ) composition with $30 \%$ transparency 


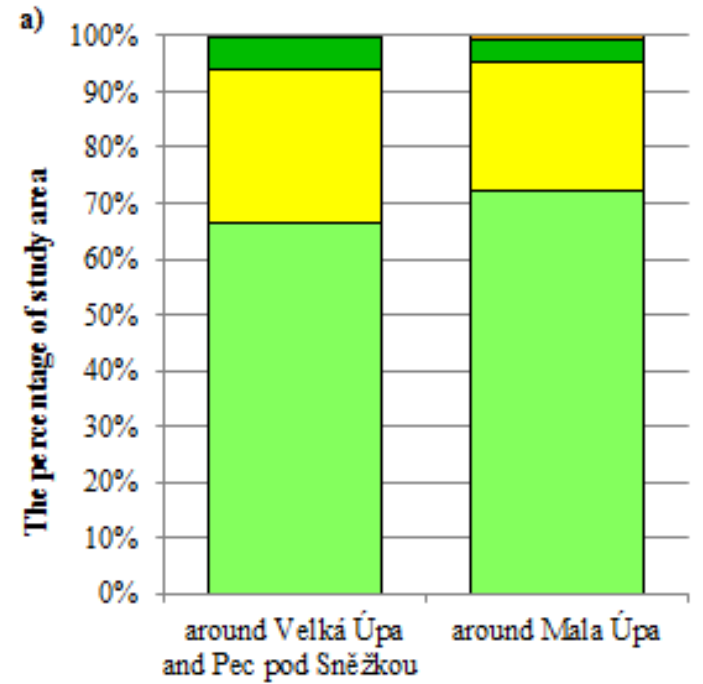

Study areas

$0-1$

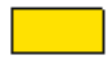

$101-3$

$301-5$

aboves b)

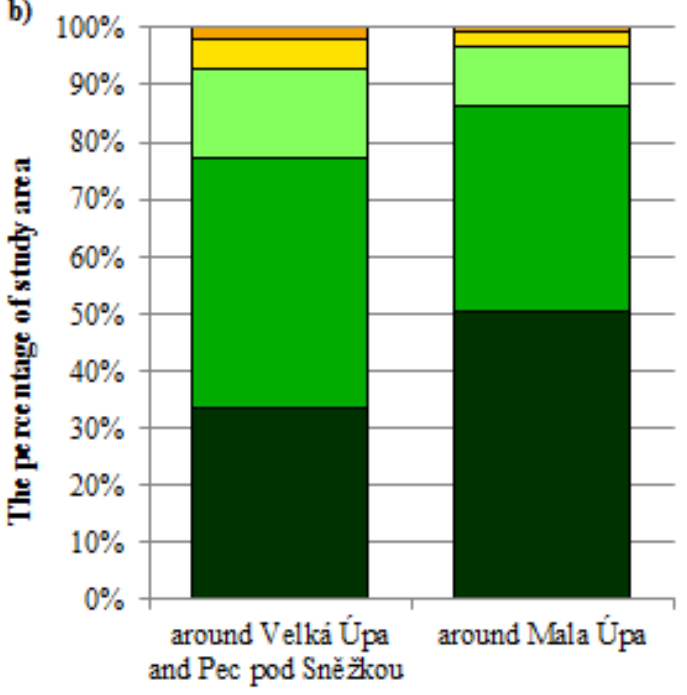

Study areas

$0-20 x$

$20.01-40 \%$

$40.01-60 \%$

$60.01-80 \%$

Figure 5. The percentage of the study area calculated for each class for the biophysical variables LAl (a) and fAPAR (b)

Sněžkou and 3.6 near Mala Úpa, so the values were quite similar. The greatest area was covered by plants with LAI between 3 and 5 (Fig. 3, 5a). The values were not very high, which could be a result of mowing and grazing, or the specific structure of montane species.

The average value of fAPAR for the grasslands around Velká Úpa and Pec pod Sněžkou was $72 \%$, whereas for the area near Mala Úpa it was $81 \%$ (Fig. 4, 5b). It appears that the productivity of the plants was greater at higher altitude.

Based on the conducted research it can be stated that the non-forest communities in the Karkonosze Mountains are in good condition. The results of plant condition are comparable to analyses conducted using Landsat data (Jarocińska et al. 2014b). The vegetation index values calculated in this study are lower than for lowland areas, which may be related to the different structure of the plants (Jarocińska \& Zagajewski 2008, Żołnierz \& Wojtuń 2013). On the other hand, the values of vegetation indices calculated using ASD FieldSpec spectrometric field measurements for alpine grasslands in the Tatra Mountains are lower compared to the results presented here (Kycko et al. 2014).

\section{References}

Cho, MA \& Skidmore, AK 2009, 'Hyperspectral predictors for monitoring biomass production in Mediterranean mountain grasslands: Majella National Park, Italy', International Journal of Remote Sensing, vol. 30(2), pp. 499-515.

Darvishzadeh, R, Atzberger, C \& Skidmore, AK 2006 , 'Hyperspectral vegetation indices for estimation of leaf area index', ISPRS Commission VII Mid-term Symposium, Enschede, the Netherlands, pp. 391-396. Available from: Purdue University: <ftp://ftp.ecn.purdue.edu/jshan/ proceedings/ISPRS_Comm7_2006/PDF\%20FIles/233\%20 Darvishzadeh/isprs2006-darvish.pdf>. [5 August 2015].
The values of the vegetation indices are higher for synanthropic communities than for grasslands, which may be a result of the morphology of synanthropic vegetation. In particular, invasive species such as Rumex alpinus L. or Lupinus polyphyllus $L$. are taller with a bigger biomass. This was confirmed by a previous study of the condition of invasive plants in the Czech Krkonoše, using in-situ measurements of the fAPAR and Leaf Area Index (LAI) parameters and comparing them to APEX imagery (Jelének et al. 2014). For synanthropic communities, the values of vegetation indices are more diverse.

Overall, APEX hyperspectral images and field measurements of biophysical variables were successfully used to analyse the condition of non-forest mountain vegetation. Because of the high spectral and spatial resolution of the APEX images, it is possible to acquire high quality information about the state of vegetation for heterogeneous, mountain communities, even on small patches of vegetation. di Bella, CM, Paruelos, JM, Becerra, JE, Bacour, C \& Baret, F 2004, 'Effect of senescent leaves on NDVI-based estimates of fAPAR: experimental and modelling evidences', International Journal of Remote Sensing, vol. 25, no. 23, pp. 5415-5427.

Fourty, T, Baret, F, Jacquemoud, S, Schmuck, G \& Verdebout, J 1996, 'Leaf Optical Properties with Explicit Description of Its Biochemical Composition: Direct and Inverse Problems', Remote Sensing of Environment, vol. 56, pp. 104-117.

Gamon, J, Penuelas, J \& Field, C 1992, 'A Narrow-Waveband Spectral Index That Tracks Diurnal Changes in 
Photosynthetic Efficiency', Remote Sensing of Environment, vol. 41, pp. 35-44.

$\mathrm{He}, \mathrm{Y}, \mathrm{Guo}, \mathrm{X}$ \& Wilmshurst, J 2006, 'Studying mixed grassland ecosystems I: suitable hyperspectral vegetation indices', Journal of Remote Sensing, vol. 23, no. 2, pp. 98-107.

Hsu, CW, Chang, CC \& Lin, CJ 2010, A practical guide to support vector classification. National Taiwan University. Taiwan. Available from: http://ntu.csie.org/ cjlin/papers/guide/guide. pdf. [5 August 2015].

Hunt, ER \& Rock, BN 1989, 'Detection of changes in leaf water content using near- and middle-infrared reflectances', Remote Sensing of Environment, vol. 30, pp. 43-54.

Jarocińska, A, 2014. Radiative Transfer Model parametrization for simulating the reflectance of meadow vegetation. Miscellanea Geographica, 18(2): 5-9.

Jarocińska, A \& Zagajewski, B 2008, ‘Korelacje naziemnych i lotniczych teledetekcyjnych wskaźników roślinności dla zlewni Bystrzanki', Teledetekcja Środowiska, vol. 40, pp. $100-125$.

Jarocińska, A, Zagajewski, B, Ochtyra, A, Marcinkowska, A \& Kupkova, L 2014a, 'PROSAIL model for reflectance simulations of mountainous non-forest communities', EARSeL eProceedings, vol. 13, no. 1, pp. 18-23.

Jarocińska, A, Zagajewski, B, Ochtyra, A, MarcinkowskaOchtyra, A, Kycko, M \& Pabjanek, P 2014b, 'Przebieg klęski ekologicznej w Karkonoszach i Górach Izerskich na podstawie analizy zdjęć satelitarnych Landsat', Wydawnictwo pokonferencyjne - konferencja naukowa $z$ okazji 55-lecia Karkonoskiego Parku Narodowego „25 lat po klęsce ekologicznej w Karkonoszach i Górach Izerskich obawy a rzeczywistość", pp. 47-61.

Jelének, J, Kupková, L, Zagajewski, B, Březina, S, Ochtyra, A \& Marcinkowska, A 2014, 'Laboratory and image spectroscopy for evaluating the biophysical state of meadow vegetation in the Krkonoše National Park', Miscellanea Geographica - Regional Studies on Development, vol. 18, no. 2, pp. 15-22.

Jensen, JR 1983, 'Biophysical Remote sensing - Review Article', Annals of the Associations of American Geographers, vol. 73(1), pp. 111-132.
Kycko, M, Zagajewski, B \& Kozłowska, A 2014, 'Variability in spectral characteristics of trampled high-mountain grasslands', Miscellanea Geographica - Regional Studies on Development, vol. 18, no. 2, pp. 10-14.

Marcinkowska, A, Zagajewski, B, Ochtyra, A, Jarocińska, E, Raczko, E, Kupková, L, Stych, P \& Meuleman, K 2014, 'Mapping vegetation communities of the Karkonosze National Park using APEX hyperspectral data and Support Vector Machines', Miscellanea Geographica - Regional Studies on Development, vol. 18, no. 2, pp. 23-29.

Myneni, RB \& Williams, DL 1994, 'On the relationship between FAPAR and NDVI', Remote Sensing of Environment, vol. 49, pp. 200-211.

Peñuelas, J, Filella, I, Biel, C, Serrano, L \& Save, R 1995, 'The reflectance at the 950-970 region as an indicator of plant water status', International Journal of Remote Sensing, vol. 14, pp. 1887-1905.

Rapp, M, Schweiger, A \& Haller, R 2013, 'Biomass-mapping of alpine grassland with APEX imaging spectrometry data, Mittersill', Conference Volume of 5th Symposium for Research in Protected Areas, pp. 631-637. Available from: $<$ http://www.zobodat.at/pdf/NP-Hohe-Tauern-Conference 5_0631-0637.pdf>. [5 August 2015].

Sims, DA \& Gamon, JA 2002, 'Relationships between leaf pigment content and spectral reflectance cross a wide range of species, leaf structures and developmental stages', Remote Sensing of Environment, vol. 81, pp. 337-354.

Ustin, SL, Roberts, DA, Gamon, JA, Asner, GP, Green, RO 2004, 'Using Imaging Spectroscopy to Study Ecosystem Processes and Properties', Bioscience, vol. 54 (6), pp. 523533.

Żołnierz, L \& Wojtuń, B 2013, 'Roślinność subalpejska i alpejska' in Przyroda Karkonoskiego Parku Narodowego eds R Knapik \& A Raj, Karkonoski Park Narodowy, Jelenia Góra, pp. 241-278.

Żołnierz, L, Wojtuń, B \& Przewoźnik, L 2012, Ekosystemy nieleśne Karkonoskiego Parku Narodowego, Karkonoski Park Narodowy, Jelenia Góra, pp. 100. 